\title{
Warming and acidification promote cyanobacterial dominance in turf algal assemblages
}

\author{
D. Bender ${ }^{1,2, *}$, G. Diaz-Pulido ${ }^{1,3}$, S. Dove ${ }^{1,2}$ \\ ${ }^{1}$ Global Change Institute and School of Biological Sciences, The University of Queensland, St. Lucia, Queensland 4072, Australia \\ ${ }^{2}$ ARC Centre of Excellence for Coral Reef Studies, The University of Queensland, St. Lucia, Queensland 4072, Australia \\ ${ }^{3}$ Present address: Griffith School of Environment \& Australian Rivers Institute, Coast and Estuaries, Griffith University, \\ Nathan, Queensland 4111, Australia
}

\begin{abstract}
As marine ecosystems are predicted to be facing increases in both temperature and $\mathrm{CO}_{2}$ levels, resulting in increased acidity, scientific research is attempting to predict the effect that the altered environmental conditions will have on species, communities and, ultimately, ecosystems. This study focused on elevated temperature and ocean acidification effects on the ubiquitous, yet often overlooked, turf algal assemblages on the Great Barrier Reef, Australia. In order to assess possible changes in relative abundance of species, biomass and productivity, 3 different levels of $\mathrm{pH}$ and 2 different levels of temperature treatments were applied to shallow water turf algal assemblages in a multifactorial (orthogonal) experiment. The eukaryotic component of the algal assemblages showed differential responses to combinations of $\mathrm{pH}$ and temperature treatments. The response was however dominated by a strong increase in the relative abundance of Lyngbya, a cyanobacterium, under acidification and higher temperature treatment levels, while other cyanobacteria, such as the Rivulariaceae, did not respond to the altered environment. Possible explanations for this observation may be differences in nitrogen fixation capacity and/or temperature optima. The biomass of the algal assemblages remained stable under all treatment levels, while changes in productivity associated with an interaction of the factors were observed. The findings of this experimental study highlight the complexity of turf algal assemblages in their composition and in their response to altered environmental conditions. However, they also support the dominant theoretical physiological predictions for eukaryotic and prokaryotic turf algae that suggest a positive or neutral response to future environmental conditions.
\end{abstract}

KEY WORDS: Climate change $\cdot$ Coral reef $\cdot$ Great Barrier Reef $\cdot$ Lyngbya $\cdot$ Ocean acidification Productivity $\cdot$ Species composition $\cdot$ Turf algae

\section{INTRODUCTION}

Marine ecosystems and a myriad of organisms are threatened by climate change and ocean acidification (Hoegh-Guldberg \& Bruno 2010, Doney et al. 2012). In particular, coral reefs are very sensitive to anomalous increases in sea surface temperature and persistent declines in $\mathrm{pH}$ (Hoegh-Guldberg et al. 2007, Dove et al. 2013). Increased $\mathrm{CO}_{2}$ concentrations can enhance algal growth and the competitive abilities of some benthic macroalgae to overgrow corals (Holbrook et al. 1988, Enriquez \& RodriguezRoman 2006, Diaz-Pulido et al. 2011, Johnson et al. 2014). However, very little is known about the 
responses of the ubiquitous turf algae to ocean acidification and elevated temperature. Turf algal assemblages grow attached to rocks, dead shells and skeletons and even on the surface of macroalgae as epiphytes, and are generally $<1 \mathrm{~cm}$ high (Steneck 1988). Furthermore, other microbial algal communities occur in reef environments, including microphytobenthos (MPB) and benthic microalgae (BMA) on sediments. MPB and BMA contain many of the same algal species that occur as part of the 'turf' or epilithic algal community (EAC) (Klumpp \& McKinnon 1992), and hence may be similarly affected by changes to their environment (Larkum et al. 1988, Heil et al. 2004). Algal turf assemblages can cover a large proportion of the substratum (e.g. up to $40-70 \%$ of hard surfaces; Borowitzka et al. 1983). Furthermore, they contribute significantly to the gross primary productivity (GPP) of coral reefs ecosystems (Adey \& Goertemiller 1987). Estimates of turf assemblage gross and net productivity are close or equal to that of the coral-Symbiodinium symbiosis (Hatcher 1988). Algal turfs also provide nitrogen to the ecosystem through the fixation of atmospheric nitrogen by cyanobacteria (Targett et al. 1995, Koop et al. 2001, Paul 2008). Given the importance of this assemblage to the energetics of coral reefs, it is fundamental to assess the responses of coral reef turf algae to ocean-related impacts of projected increases in atmospheric $p \mathrm{CO}_{2}$ and temperature.

A recent study has investigated the effects of ocean acidification and increasing sea surface temperature on the turf assemblages of a temperate kelp forest (Connell \& Russell 2010). The response of these temperate assemblages to combinations of acidification and nutrient enrichment has also been investigated (Russell et al. 2009). Both of these studies were, however, conducted on turf assemblages that were dominated by one brown algal genus (Feldmannia). Coral reef algal turfs, by contrast, are rather complex assemblages, consisting of filamentous green, brown and red algae, and cyanobacteria and juvenile stages of macroalgae (Wanders 1976, Adey \& Goertemiller 1987). Turf algal communities are diverse assemblages that are also subject to very high turnover rates, facilitated by intense grazing, demonstrating the importance of turf algae to the supply of energy to the ecosystem (Klumpp et al. 1987). Due to the high species diversity of turf algal assemblages, predictions about their performance in the future in terms of species composition, productivity and biomass, would currently be very speculative, and would have to be based on theoretical considera- tions. Changes to the assemblage structure of turf algae, however, can have important implications for the functioning of coral reef ecosystems.

Theoretical considerations on the effects of warming and acidification tend to focus on their impact on algal photosynthesis, which is dissected into: the carbon-concentrating mechanisms in use $(\mathrm{CCM}$, presence/absence as well as differences in the actual mechanism); the thermal optima of key enzymes; the affinity of Ribulose-1,5-bisphosphate carboxylase oxygenase (RubisCO) for $\mathrm{CO}_{2}$ and the rate at which RubisCO fixes $\mathrm{CO}_{2} / \mathrm{O}_{2}$ (Beardall et al. 1998). CCMs have developed in oxygenic photosynthetic organisms to compensate for the relatively low carbon dioxide affinity and the poor substrate discrimination of RubisCO, which is significantly under-saturated for $\mathrm{CO}_{2}$, under present-day $\mathrm{CO}_{2}: \mathrm{O}_{2}$ ratios. The potential for $\mathrm{CO}_{2}$ under-saturation of RubisCO is further increased for marine photoautotrophs due to the fact that current marine $\mathrm{pH}$ favours bicarbonate as opposed to $\mathrm{CO}_{2}$ (Beardall et al. 1998, Zeebe \& WolfGladrow 2001). Therefore, most algae and all cyanobacteria, especially marine species, have some mode of CCM (Raven et al. 2005) that by definition will concentrate $\mathrm{CO}_{2}$ at the site of fixation (Raven 2003). Eukaryotic algal species without CCMs have been identified. These species seem to rely on diffusive $\mathrm{CO}_{2}$ transport from the medium into the tissue (Raven et al. 2005). If, under ocean acidification conditions, the $\mathrm{CO}_{2}$ concentration is increased, then species relying on $\mathrm{CO}_{2}$ influx without the aid of CCMs are expected to benefit (Raven 1997b, Beardall \& Giordano 2002). Algae with CCMs and cyanobacteria are expected to show little or no changes in productivity, and benefits are unlikely if the algae maintain their CCMs. Photoautotrophs relying on CCMs are expected to rely mostly on bicarbonate uptake, and the bicarbonate concentration will increase relatively little with rising $p \mathrm{CO}_{2}$ (Raven 1997b, Beardall et al. 1998). If CCMs are down-regulated, which has been described for some eukaryotic macro- and microalgal species exposed to increased $\mathrm{CO}_{2}$ only, then productivity might be increased (Beardall \& Giordano 2002, Cornwall et al. 2012). The benefit is argued to be imbued by potential reductions in CCM maintenance costs, with savings varying dependent on the specific CCM mechanisms involved (Kübler \& Raven 1994, Beardall et al. 1998, Beardall \& Giordano 2002, Moazami-Goudarzi \& Colman 2012).

The effect of temperature on photoautotrophs, however, could either stimulate or decrease productivity. An increase in temperature usually causes 
metabolic rates to increase, which may have a positive effect on the algae through increased photosynthesis (Davison 1991). However, at higher temperatures RubisCO becomes less efficient at discriminating oxygen from carbon dioxide, and photosynthetic rates decrease (Osborne \& Beerling 2006). The positive effect would only prevail as long as the CCM is very efficient at delivering $\mathrm{CO}_{2}$ to RubisCO and therefore maintaining a high $\mathrm{CO}_{2}$ concentration at the site of fixation, otherwise temperature increases may enhance RubisCO oxygenase activity. CCMs have shown mixed responses to elevated temperature, especially relating to carbonic anhydrase activity; therefore their response is difficult to predict (Beardall \& Giordano 2002).

From the listed hypothetical responses of algae to future environments, a conclusion has been drawn that algae will either show no, or a positive response to potential future ocean environments (Beardall et al. 1998). In terms of coral reefs, this has led to predictions of potential phase shifts to eukaryotic algae, based on the assumption that algae take over from coral, and that corals will be significantly impaired by future conditions (Hughes et al. 2010). Although other organisms that may be able to dominate besides just coral and eukaryotic algae have been identified, e.g. sponges (Nyström et al. 2008), phase shifts to organisms other than macroalgae, e.g. to the prokaryotic components of turf algae, are typically not considered. In the present study, an experiment was conducted to determine whether the theoretical response of turf algal assemblages to future increased temperature and/or acidity is justified. The stability of assemblages depends on many parameters, among them their biodiversity and species interactions (Ives \& Carpenter 2007). Perturbations, such as elevated sea surface temperatures as well as changes in $\mathrm{pH}$, can cause a system to reach another stable state by going through a phase shift (Nyström et al. 2000). For any particular algal assemblage, a change in seawater (SW) parameters could lead to shifts in the abundance of certain species due to physiological traits, which in turn can alter species interactions. The specific aims of this study were, therefore, to assess the changes in species composition, productivity and biomass of turf algal samples from a coral reef (Lizard Island, Great Barrier Reef [GBR], Australia) in response to the isolated effects of elevated sea surface temperature, ocean acidification and the interactions between both processes. Shifts in the assemblage composition were assessed at 2 levels of precision in order to detect changes that may occur within the genus or species level.

\section{MATERIALS AND METHODS}

In order to assess the effects of ocean acidification and temperature increase on coral reef turf algal assemblages, an experiment was conducted at Lizard Island Research Station (LIRS) on the GBR, Australia. The experiment ran for $7 \mathrm{wk}$ in late spring/austral summer (23 October 2009 until 13 December 2009). The turf algal samples consisted of recently dead coral skeleton of the genus Porites that were 100\% covered with a mixed turf algal assemblage. The chips of coral rock were collected at low tide at Trawler Beach reef from a depth of about $1.5 \mathrm{~m}$ using hammer and chisel, and were between 1 and $2 \mathrm{~cm}^{2}$ in size and about $0.5 \mathrm{~cm}$ high. These samples were then placed under different treatment conditions with 1 coral chip per tank and 5 replicate tanks per treatment. The aquaria had a capacity of $15 \mathrm{l}$ and the water inflow was kept constant at $36 \mathrm{l} \mathrm{h}^{-1}$, while the water movement inside the aquaria was provided by a powerhead (Clearpond, Infiniti 800). Tanks were exposed to natural solar radiation, reduced to $50 \%$ by shade cloth as the light intensity on the aquarium deck would typically reach values $>1400 \mu \mathrm{mol} \mathrm{m}^{-2} \mathrm{~s}^{-1}$.

This study examined the isolated and combined

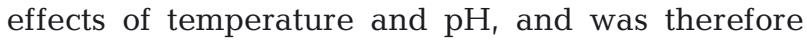
designed as an orthogonal experiment so that each factor could be evaluated independently as well as their interactions. Four $\mathrm{pH}$ levels, two of which represented distinct scenarios (B1 and A1FI scenarios, IPCC Special Report on Emission Scenarios; IPCC 2007), were crossed with 2 levels of temperature. The treatment combinations were the following: preindustrial (PI) SW $p \mathrm{CO}_{2}$ (equivalent to $\mathrm{pH} 8.2$ ), B1 SW $p \mathrm{CO}_{2}\left(\mathrm{CO}_{2}\right.$ scenario that is associated with significant reductions in the current rate of $\mathrm{CO}_{2}$ emissions by 2050, $\mathrm{pH} 7.9)$, A1FI SW $p \mathrm{CO}_{2}\left(\mathrm{a} \mathrm{CO}_{2}\right.$ scenario that is associated with no reduction in the current rate of $\mathrm{CO}_{2}$ emissions by 2050, $\mathrm{pH}$ 7.6), and a present-day (PD) SW $p \mathrm{CO}_{2}$ (spring ambient measured at $\mathrm{pH} 8.07 \pm 0.0017$, mean $\pm \mathrm{SE}$ ) were each subjected to spring ambient $\mathrm{PD}$ temperature (PD-temp: $27.9 \pm 1.55^{\circ} \mathrm{C}$, mean $\pm \mathrm{SE}$ ) and spring elevated $\mathrm{B} 1$ temperature (B1-temp: ambient $+2.3^{\circ} \mathrm{C}, 29.85 \pm$ $1.73^{\circ} \mathrm{C}$ ). Appropriate $\mathrm{pH}$ levels were attained by bubbling $\mathrm{CO}_{2}$ through SW in sumps (200 l, one per treatment) that fed experimental aquaria ( $\mathrm{n}=5$ per treatment), following methods described by DiazPulido et al. (2014). The $\mathrm{pH}_{\mathrm{SW}}$ (SW scale) inside these sumps was logged every 10 min using a $\mathrm{pH}$ sensor (Mettler Toledo, InPro4501VP) connected to a controller unit (Aquatronica ACQ110). Fig. 1a shows the 

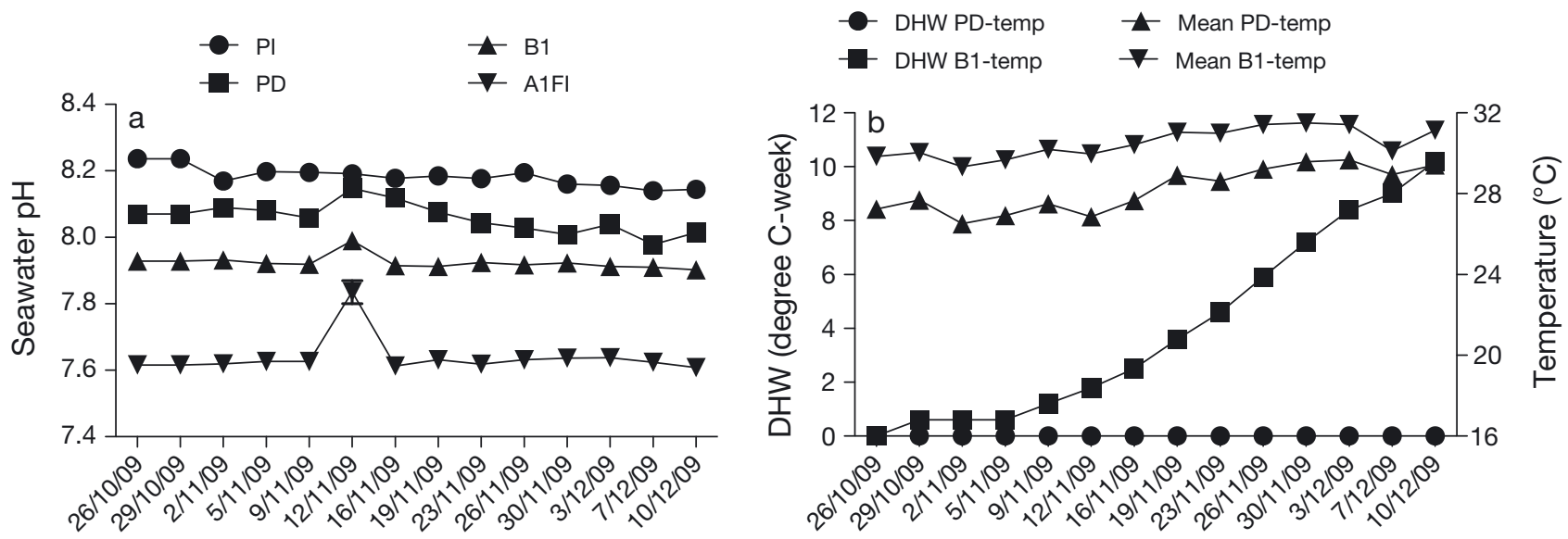

Fig. 1. (a) $\mathrm{pH}$ data as measured in the 4 different $\mathrm{pH}$ treatment sumps as a diurnal average (mean $\pm \mathrm{SE}$ ) to match the dates (given as dd/mm/yy) of the degree heating week (DHW) data. (b) Left $y$-axis: DHW data calculated from the bi-weekly NOAA/NESDIS dataset, the maximum monthly mean at Lizard Island $\left(28.9^{\circ} \mathrm{C}\right)$ and the average daily data for the ambient and elevated temperature treatment. Right $y$-axis: the measured mean temperatures of ambient (PD-temp) and elevated temperature treatments (B1-temp). PI: pre-industrial $\mathrm{pH} ; \mathrm{PD}$ : present-day $\mathrm{pH}_{;} \mathrm{B} 1: \mathrm{pH}$ treatment reflecting a $\mathrm{CO}_{2}$ scenario that is associated with significant reductions in the current rate of $\mathrm{CO}_{2}$ emissions by 2050; A1FI: $\mathrm{pH}$ treatment reflecting a $\mathrm{CO}_{2}$ scenario that is associated with no reduction in the current rate of $\mathrm{CO}_{2}$ emissions by 2050

$\mathrm{pH}$ values obtained in the treatment sumps during the experiment. The controller unit kept the $\mathrm{pH}$ stable (B1-pH $7.89 \pm 0.0058$, A1FI-pH $7.63 \pm 0.003$, mean $\pm \mathrm{SE}$ ) by opening solenoid valves that would then inject $\mathrm{CO}_{2}$ into the water. The $p \mathrm{CO}_{2}$ in the PI treatment (referred to as 'PI- $\mathrm{pH}^{\prime}$ ) was reduced by passing air through 2 PVC tubes $(1.2 \mathrm{~m})$, in series, each containing 121 of soda lime (Spherasorb, Intersurgical). This air was then injected into the PI sump, where $\mathrm{CO}_{2}$ could be added if the $\mathrm{pH}$ was too high using the same technique as for the A1FI and B1 treatments. $\mathrm{pH}$ and $p \mathrm{CO}_{2}$ were not adjusted in the PD sump, and therefore reflected conditions for SW piped into LIRS (referred to as PD-pH). The temperature was raised inside the experimental aquaria using aquarium heaters (Aqua One, $100 \mathrm{~W}$ ). Water samples were taken according to methods described in Diaz-Pulido et al. (2014) to measure total alkalinity (TA) using an auto-titrator (Metrohm) at Edith Cowan University, Western Australia. Using the program CO2sys (Lewis \& Wallace 1997), $p \mathrm{CO}_{2}$, total inorganic carbon, bicarbonate and carbonate concentrations were calculated from the TA and $\mathrm{pH}$ data (using K1 and K2 from Mehrbach et al. 1973, refit by Dickson \& Millero 1987, an ambient temperature of $28^{\circ} \mathrm{C}$ and salinity 35.3 ).

After the experimental period, respirometry measurements were performed. The maximum net productivity $\left(\mathrm{P}_{\mathrm{nmax}}\right)$, dark respiration, and light-enhanced dark respiration (LEDR) were measured and GPP was estimated (as described in Crawley et al. 2010). The $\mathrm{O}_{2}$ flux of the endolithic organisms present in the coral chips was included in these measurements, but their contribution to the $\mathrm{O}_{2}$ exchange was assumed to be small compared to turf algal productivity (Schlichter et al. 1997). The samples were darkadapted for $45 \mathrm{~min}$; subsequently the dark respiration was recorded for 10 min using fiber optic oxygen probes (Oxy4 v2, PreSens). The dark period (light intensity $0 \mu \mathrm{mol} \mathrm{m} \mathrm{m}^{-2} \mathrm{~s}^{-1}$ measured using a LI-COR LI250A Light Meter and LI-192 Underwater Quantum Sensor) was followed by $15 \mathrm{~min}$ of maximum illumination (900 $\mu \mathrm{mol} \mathrm{m}^{-2} \mathrm{~s}^{-1}$ ) measuring $\mathrm{P}_{\mathrm{nmax}}$ and again 10 min of darkness in order to record LEDR immediately following dimming. After an extra $20 \mathrm{~min}$ in darkness, a light curve (PI curve, data not shown) was recorded to ensure light saturation during $\mathrm{P}_{\mathrm{nmax}}$ measurements. All respirometry measurements were performed in $0.45 \mu \mathrm{m}$ filtered $\mathrm{SW}$ at treatment $\mathrm{pH}$ and temperature. Animals, if present and visible with the naked eye, were removed prior to measurements. Illumination during oxygen flux measurements was provided by a $150 \mathrm{~W}$ lamp (Ocean Light T5 MH combo) with two 24 Ocean Blue Actinic light bulbs (Aqua-Medic).

The relative abundance of turf algal genera present on each sample was estimated. Relative abundance was determined for $1 \mathrm{~cm}^{2}$ quadrats consisting of 25 squares viewed under a dissection microscope. For each square, only the most abundant genus was 
counted. Cyanobacteria cannot be distinguished at this level of magnification, and were therefore not further differentiated. In order to estimate the relative abundance of turf algal species, a sample was taken by scraping all turf algae off a random $4 \times 4 \mathrm{~mm}$ square on each coral chip. These algae were then decalcified using $1 \mathrm{M} \mathrm{HCl}$ and stained with aniline blue to highlight algal features (Price \& Scott 1992). Finally, the samples were spread evenly onto a microscopic slide and the relative abundance of algae species was estimated by scoring the percent cover of species in 5 microscopic fields per slide (magnification 100×) (Diaz-Pulido \& McCook 2002). The Polysiphonieae (Rhodophyta) were, due to the lack of reproductive and other characteristics used for identification in many samples, not analyzed to species level, but included members of the genera Polysiphonia and Neosiphonia. The relative abundance data based on both genus- and species-level identification were obtained in the beginning and at the end of the experiment, and percent change in relative abundance of the algal assemblage was calculated and used in the multivariate analysis. Algal genera and species were identified using the following references: Womersley $(1984,1987,2003)$, Anagnostidis \& Komárek (1988), Price \& Scott (1992), Abbott (1999), Abbott \& Huisman (2004), Kim \& Abbott (2006), Kraft (2007) and the AlgaeBase website (www.algaebase.org).

The biomass of each sample, of the turf algae and of the endolithic assemblage component, was determined. The coral chips were rinsed in freshwater to remove excess salt prior to scraping off the algae with a scalpel. The turf algae and the coral chips were then decalcified in $1 \mathrm{M} \mathrm{HCl}$ (turf algae for $4 \mathrm{~h}$ in $10 \mathrm{ml}$ of $1 \mathrm{M} \mathrm{HCl}$ and the coral chips for $5 \mathrm{~d}$ and $80 \mathrm{ml} 1 \mathrm{M} \mathrm{HCl}$ ). Following $\mathrm{CaCO}_{3}$ dissolution, the samples were filtered through pre-weighed glass fiber filters to capture all biomass $(0.7 \mu \mathrm{m}$ pore size) that had been combusted in a muffle furnace at $550^{\circ} \mathrm{C}$ for $5 \mathrm{~h}$. Filter papers with samples were dried to a stable weight at $60^{\circ} \mathrm{C}$ for $48 \mathrm{~h}$ after which the dry weight was recorded. They were then combusted in the furnace at $550^{\circ} \mathrm{C}$ for $5 \mathrm{~h}$. After this procedure, the ash free dry weight (AFDW) was estimated by subtracting the weight after combustion from the samples' dry weight. The respirometry data were then normalized to AFDW $\left(\mu \mathrm{mol} \mathrm{O}_{2}\right.$ $\mathrm{mg}_{\mathrm{AFDW}}{ }^{-1} \mathrm{~h}^{-1}$ ).

The algal assemblage structure was analyzed using PRIMER v6 software and PERMANOVA + add on (PRIMER-E) for genus and species level separately. A Bray Curtis Similarity was used for the
PERMANOVA, which was run as a type III analysis, using the method of permutation of residuals under a reduced model (factors: $\mathrm{pH}$ and temperature, both fixed). A dummy variable $(+1)$ was added to the untransformed data in order to deal with the great variability of the algal abundance. An MDS plot based on the Bray Curtis similarity to better show variability of the composition of the algal assemblage was computed. The single species responses collected using the compound microscope, the genus-level responses collected using the dissection microscope, and the biomass and respirometry data were analyzed using Statistica v9 (StatSoft). The single species response was only statistically analyzed (using 2-way ANOVAs) if a change of $>10 \%$ in species composition was observed in any treatment. For biomass, respirometry and single species responses, 2-way ANOVAs were run, the fixed factors being temperature ( 2 levels) and $\mathrm{pH}$ treatment (4 levels). Tukey's post-hoc test and pair-wise comparisons were performed on significant results. After no significant difference was found in the abundance of algal genera under the different $\mathrm{pH}$ and temperature treatments in the PERMANOVA, the data for brown, green, red algae and cyanobacteria were pooled for the 2 time points (beginning and end of the experiment). Subsequently, one-way ANOVAs were performed for the different algal types in order to elucidate differences in abundance across treatments.

To place the $+2^{\circ} \mathrm{C}$ degree temperature increase applied in the experiment into context, Degree Heating Weeks (DHWs) for the experimental treatments were calculated following the National Oceanic and Atmospheric Administration (NOAA) protocol, and based on established maximum monthly mean (MMM) for Lizard Island of $28.9^{\circ} \mathrm{C}$ (NOAA 2014). DHWs measure the accumulation of heat stress $\left(\mathrm{MMM}+1^{\circ} \mathrm{C}\right)$, over a $12 \mathrm{wk}$ rolling window, on a scale from 0 to 16 , and are used to predict possible coral bleaching events (NOAA 2011).

\section{RESULTS}

In order to assess possible changes in turf algal assemblage composition, productivity and biomass under future conditions, coral chips overgrown with epilithic algae were subjected to different temperature and $\mathrm{pH}$ regimes. The following $\mathrm{pH}$ values were reached in the respective treatments (mean $\pm \mathrm{SE}$ ): PIpH $8.2 \pm 0.03 ;$ PD-pH $8.1 \pm 0.01 ;$ B1-pH $7.9 \pm 0.01$; A1FI-pH $7.6 \pm 0.01$ (Table 1). $p \mathrm{CO}_{2}$ and bicarbonate 
Table 1. Carbon chemistry of the $\mathrm{pH}$ treatments calculated from samples taken from the experimental sumps (mean $\pm \mathrm{SE}$ ) using CO2sys software. PI: pre-industrial; PD: present-day; B1: $\mathrm{pH}$ treatment reflecting a $\mathrm{CO}_{2}$ scenario that is associated with significant reductions in the current rate of $\mathrm{CO}_{2}$ emissions by 2050; A1FI: $\mathrm{pH}$ treatment reflecting a $\mathrm{CO}_{2}$ scenario that is associated with no reduction in the current rate of $\mathrm{CO}_{2}$ emissions by $2050 ; \mathrm{pH}_{\mathrm{Sw}}$ : $\mathrm{pH}$ seawater scale

\begin{tabular}{|lcccccc|}
\hline $\begin{array}{l}\mathrm{pH} \\
\text { treatment }\end{array}$ & $\begin{array}{c}\text { Total alkalinity } \\
\left.(\mathrm{mg} \mathrm{kg})^{-1}\right)\end{array}$ & $\mathrm{pH}$ Sw & $\begin{array}{c}\text { Total carbon } \\
(\mu \mathrm{mol} \mathrm{kg})\end{array}$ & $\begin{array}{c}\mathrm{COO}_{2} \\
(\mu \mathrm{atm})\end{array}$ & $\begin{array}{c}\mathrm{HCO}_{3}^{-} \\
\left(\mu \mathrm{mol} \mathrm{kg}^{-1}\right)\end{array}$ & $\begin{array}{c}\mathrm{CO}_{3}{ }^{-2} \\
\left(\mu \mathrm{mol} \mathrm{kg}^{-1}\right)\end{array}$ \\
\hline PI & $2393 \pm 6$ & $8.2 \pm 0.03$ & $1974 \pm 24$ & $295 \pm 24$ & $1671 \pm 35$ & $295 \pm 12$ \\
PD & $2398 \pm 6$ & $8.1 \pm 0.01$ & $2026 \pm 12$ & $357 \pm 14$ & $1751 \pm 17$ & $265 \pm 5$ \\
B1 & $2401 \pm 8$ & $7.9 \pm 0.01$ & $2126 \pm 12$ & $555 \pm 16$ & $1909 \pm 14$ & $202 \pm 3$ \\
A1FI & $2399 \pm 7$ & $7.6 \pm 0.01$ & $2267 \pm 9$ & $1210 \pm 29$ & $2121 \pm 9$ & $114 \pm 2$ \\
\hline
\end{tabular}

increased and carbonate ions decreased from PI-pH through to A1FI-pH (Table 1). The mean temperature under B1-temp $\left(30.47 \pm 0.87^{\circ} \mathrm{C}\right.$, mean $\left.\pm \mathrm{SE}\right)$ was $2.3^{\circ} \mathrm{C}$ above PD-temp $\left(28.18 \pm 1.35^{\circ} \mathrm{C}\right.$, mean \pm $\mathrm{SE}$ ). The DHW data (Fig. 1b) indicate that our spring PD-temp regime is nonstressful to a coral reef assemblage with a DHW of 0 throughout the experiment, while the elevated temperature treatment showed a considerable build-up of temperature stress, attaining a DHW of 4 half-way through and a DHW of 10 at the end the experiment.

\section{Assemblage analysis at the level of algal genera}

About 20 different algal and cyanobacterial genera were found using a dissection microscope to determine the relative abundance of algae. At the beginning of the experiment, the algal turf assemblages growing on coral chips were dominated by brown algae, while green algae and cyanobacteria were less abundant (1-way ANOVA: p = 0.002, brown algae > green algae = cyanobacteria, Fig. 2b). At the end of the experiment, the assemblages were dominated by cyanobacteria and red algae (1-way ANOVA: $p=0.001$, cyanobacteria > green $=$ brown and cyanobacteria $=$ red, Fig. 2c). However, the treatments had no significant effect on the change in abundance of algal genera (PERMANOVA, $\mathrm{p}($ perm $)>0.05$, Table 2), with algal genera found to be highly variable between samples (Fig. 2a).
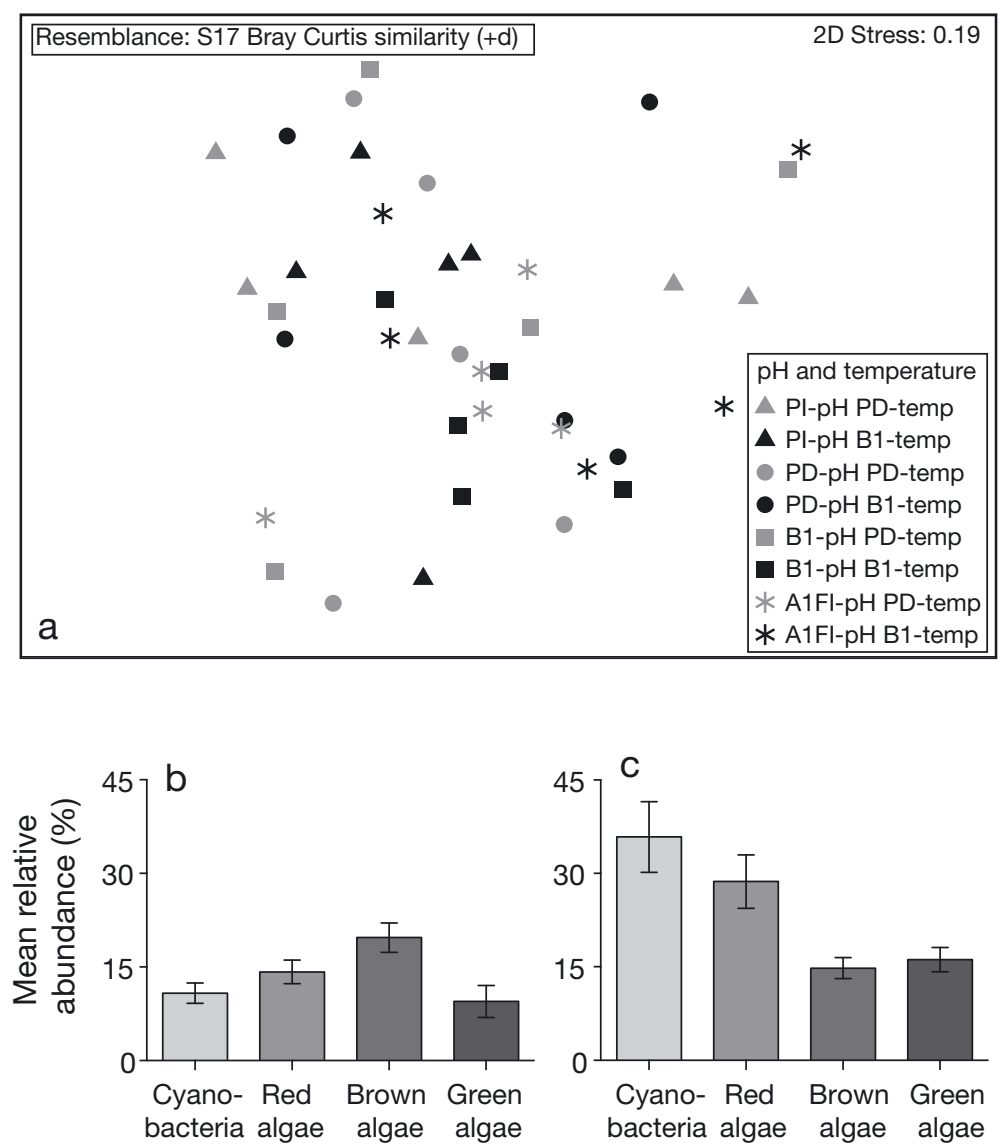

Fig. 2. Species composition of the turf algal assemblage. (a) MDS plot based on the change of mean relative abundance (\%) of algal genera between the beginning and end of the experiment in the turf algae samples under the different seawater $\mathrm{pH}$ and temperature regimes, every data point represents one sample. $\mathrm{n}=5$ coral chips per treatment. $(b, c)$ Mean relative abundance $( \pm \mathrm{SE})$ of the turf algal assemblage (b) at the beginning and (c) at the end of the experiment. Algae are grouped as red, brown, and green algae. $\mathrm{n}=40$. PD-temp: present-day temperature; B1-temp: elevated temperature; PI: pre-industrial $\mathrm{pH}_{i} \mathrm{PD}$ : present-day $\mathrm{pH} ; \mathrm{B} 1: \mathrm{pH}$ treatment reflecting a $\mathrm{CO}_{2}$ scenario that is associated with significant reductions in the current rate of $\mathrm{CO}_{2}$ emissions by 2050; A1FI: $\mathrm{pH}$ treatment reflecting a $\mathrm{CO}_{2}$ scenario that is associated with no reduction in the current rate of $\mathrm{CO}_{2}$ emissions by 2050 
Table 2: PERMANOVA and 2-way ANOVA of the turf algal assemblages. ANOVA was performed for turf algae that underwent $>10 \%$ change in 1 treatment; table shows species for which significant treatment effects were found. Non-significant effects were found in the following taxa: Rivulariaceae, Bryobesia johannae Weber-van Bosse, Anotrichium tenue (C.Agardh) Nägeli, Sphacelaria tribuloides Meneghini, Hincksia mitchelliae (Harvey) P.C.Silva. pH: pH treatments; B1T: B1-temperature; PDT: present-day or ambient temperature; PI: pre-industrial $\mathrm{pH}$ treatment; PD: present-day $\mathrm{pH}$ treatment; $\mathrm{B} 1$ : $\mathrm{pH}$ treatment reflecting a $\mathrm{CO}_{2}$ scenario that is associated with significant reductions in the current rate of $\mathrm{CO}_{2}$ emissions by $2050 ; \mathrm{A} 1 \mathrm{FI}$ : $\mathrm{pH}$ treatment reflecting a $\mathrm{CO}_{2}$ scenario that is associated with no reduction in the current rate of $\mathrm{CO}_{2}$ emissions by 2050; ns: not significant if $\mathrm{p} \geq 0.05$

\begin{tabular}{|c|c|c|c|c|c|c|c|}
\hline Response variable & $\begin{array}{l}\text { Source of } \\
\text { variation }\end{array}$ & SS & $\mathrm{df}$ & MS & (Pseudo)-F & $\mathrm{p}($ perm $)$ & $\begin{array}{l}\text { Conclusions/ } \\
\text { Post-hoc test }\end{array}$ \\
\hline \multicolumn{8}{|l|}{ PERMANOVA } \\
\hline \multirow[t]{3}{*}{ Abundance of genera } & $\mathrm{T}$ & 12.22 & 1 & 12.2 & 0.7 & 0.6 & ns \\
\hline & $\mathrm{pH}$ & 42.4 & 3 & 14.1 & 0.8 & 0.6 & ns \\
\hline & $\mathrm{T} \times \mathrm{pH}$ & 43.2 & 3 & 14.4 & 0.9 & 0.6 & ns \\
\hline \multirow[t]{3}{*}{ Abundance of species } & $\mathrm{T}$ & 13.5 & 1 & 13.5 & 1.8 & 0.08 & ns \\
\hline & $\mathrm{pH}$ & 24.4 & 3 & 8.1 & 1.1 & 0.35 & ns \\
\hline & $\mathrm{T} \times \mathrm{pH}$ & 45.4 & 3 & 15.1 & 2 & 0.007 & $\begin{array}{l}\text { PDT: } \mathrm{A} 1 \mathrm{FI} \neq \mathrm{PD} ; \mathrm{B} 1 \mathrm{~T}: \mathrm{A} 1 \mathrm{FI} \neq \\
\text { B1; } \mathrm{pH}: \mathrm{A}_{1} \mathrm{FI}_{\mathrm{PDT}} \neq \mathrm{A}_{1 \mathrm{FI}} \mathrm{B}_{\mathrm{T}}\end{array}$ \\
\hline \multicolumn{8}{|l|}{ ANOVA } \\
\hline Lyngbya C. & $\mathrm{T}$ & 1128 & 1 & 1128 & 2 & 0.16 & ns \\
\hline \multirow[t]{2}{*}{ Agardh ex Gomont } & $\mathrm{pH}$ & 2160 & 3 & 720 & 1 & 0.3 & ns \\
\hline & $\mathrm{T} \times \mathrm{pH}$ & 7005 & 3 & 2335 & 4 & 0.012 & $\mathrm{~A} 1 \mathrm{FI}_{\mathrm{B} 1 \mathrm{~T}}>\mathrm{B} 1_{\mathrm{B} 1 \mathrm{~T}}=\mathrm{A} 1 \mathrm{FI}_{\mathrm{PDT}}$ \\
\hline \multirow[t]{3}{*}{ Polysiphonieae } & $\mathrm{T}$ & 0.00 & 1 & 0.0000004 & 0.000084 & 0.9 & $\mathrm{~ns}$ \\
\hline & $\mathrm{pH}$ & 0.01 & 3 & 0.004 & 0.75 & 0.5 & ns \\
\hline & $\mathrm{T} \times \mathrm{pH}$ & 0.06 & 3 & 0.02 & 4.03 & 0.015 & $\mathrm{~A} 1 \mathrm{FI}_{\mathrm{PDT}}>\mathrm{PI}_{\mathrm{PDT}}$ \\
\hline \multirow{3}{*}{$\begin{array}{l}\text { Sphacelaria novae- } \\
\text { hollandiae Sonder }\end{array}$} & $\mathrm{T}$ & 4503 & 1 & 4503 & 5 & 0.026 & $\mathrm{PDT}>\mathrm{B} 1 \mathrm{~T}$ \\
\hline & $\mathrm{pH}$ & 1464 & 3 & 488 & 1 & 0.6 & ns \\
\hline & $\mathrm{T} \times \mathrm{pH}$ & 238 & 3 & 79 & 0.10 & 1.0 & ns \\
\hline \multirow{3}{*}{$\begin{array}{l}\text { Sphacelaria rigidula } \\
\text { Kützing }\end{array}$} & $\mathrm{T}$ & 652 & 1 & 652 & 7 & 0.012 & $\mathrm{~B} 1 \mathrm{~T}>\mathrm{PDT}$ \\
\hline & $\mathrm{pH}$ & 528 & 3 & 176 & 2 & 0.1 & ns \\
\hline & $\mathrm{T} \times \mathrm{pH}$ & 177 & 3 & 59 & 1 & 0.6 & ns \\
\hline \multirow{3}{*}{$\begin{array}{c}\text { Cladophora feredayoides } \\
\text { Kraft \& A.J.K.Millar }\end{array}$} & $\mathrm{T}$ & 0.006 & 1 & 0.006 & 6 & 0.018 & \\
\hline & $\mathrm{pH}$ & 0.009 & 3 & 0.003 & 3 & 0.035 & \\
\hline & $\mathrm{T} \times \mathrm{pH}$ & 0.014 & 3 & 0.005 & 5 & 0.006 & $\mathrm{PD}_{\mathrm{PDT}}<$ all \\
\hline
\end{tabular}

\section{Assemblage analysis at the level of algal species}

Significant differences were observed at higher resolution using a compound microscope and stained samples to analyze the change in relative abundance of turf algal species. With this more precise method, a significant interaction between SW temperature and $\mathrm{pH}$ was found (PERMANOVA, $\mathrm{p}($ perm $)=0.007$, Table 2). The data suggest that within the PD-temp treatment, the percent change in relative abundance of species under A1FI-pH was different from the PD$\mathrm{pH}$. Within the B1-temp treatment, the assemblages in the B1-pH and A1FI-pH treatments were also significantly different from one another. Lastly, the assemblages exposed to A1FI-pH under PD-temp and B1-temp were also significantly different from one another.

The microscopic analysis revealed Rivulariaceae and Lyngbya spp. C.Agardh ex Gomont as the dom- inant cyanobacteria: Rivulariaceae, averaged across all $\mathrm{pH}$ and temperature treatments, had a stable relative abundance of $12 \pm 2 \%$ in the beginning and $13 \pm 2 \%$ at the end of the experiment, and Lyngbya's relative abundance increased from $2.4 \pm 1.3$ to $25 \pm 4 \%$ during the course of the experiment (mean $\pm \mathrm{SE}$ ). The change in relative abundance of several algal taxa over time was found to be significantly affected by the temperature and $\mathrm{pH}$ treatments (Table 2, Fig. 3), while other algae showed no effect ( $p>0.05$, see Table 2 for a listing). For the relative abundance of Lyngbya, an interaction (a synergism) was found between $\mathrm{pH}$ and temperature: the combination of A1FI-pH/B1-temp led to an increase in the abundance of Lyngbya compared to B1-pH/B1temp and A1FI-pH/PD-temp (2-way ANOVA, p = 0.02 , Table 2). This led to the dominance of the turf algal assemblage by Lyngbya under the combination of A1FI-pH and B1-temp. The Polysiphonieae (Rhodophyta) showed an increase in abundance 


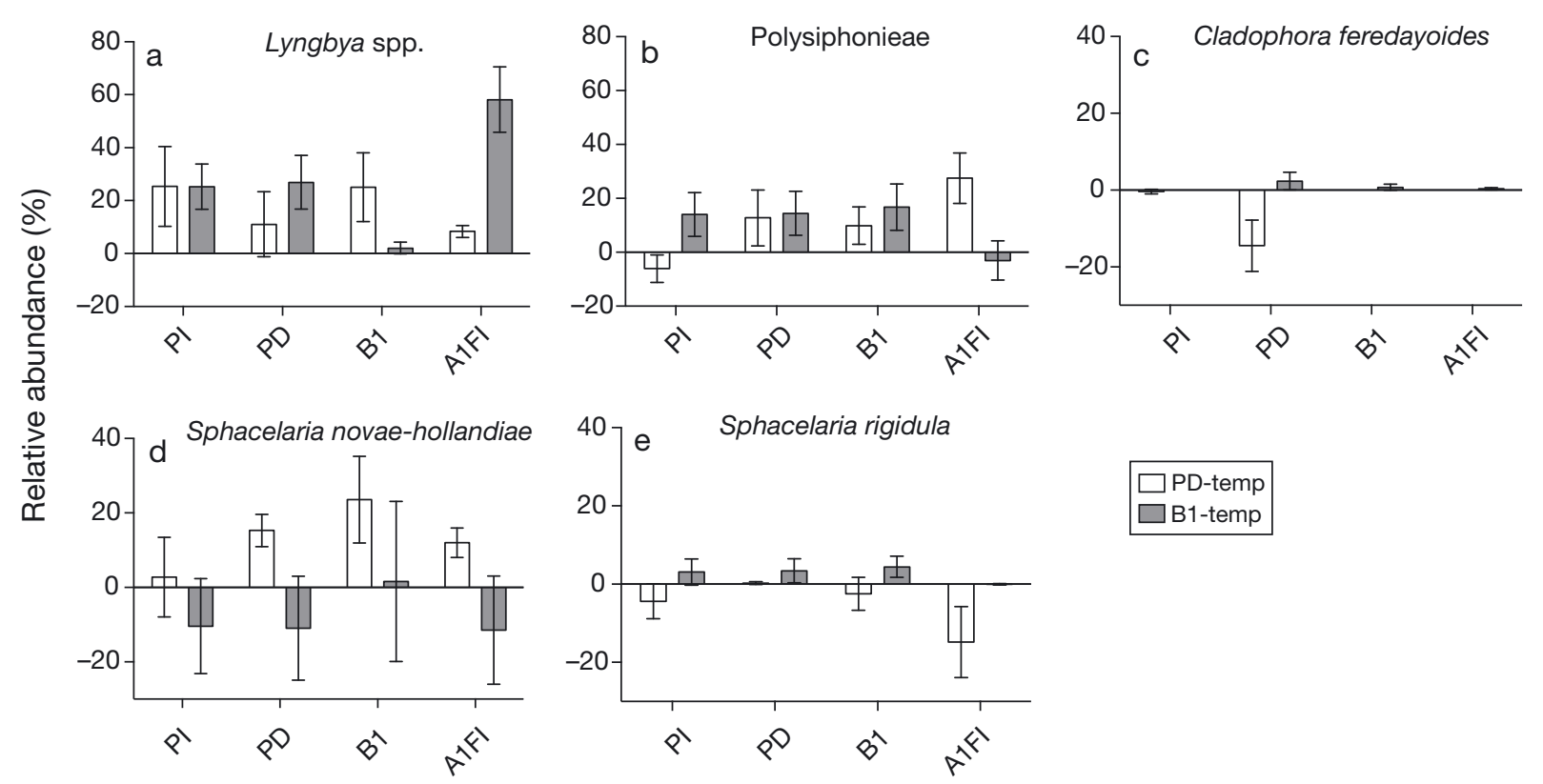

Fig. 3. Specific responses in percent change in the relative abundance (mean $\pm \mathrm{SE}$ ) of algal species and cyanobacterial genera under the different $\mathrm{pH}$ and temperature regimes. (a) Cyanobacterial genus Lyngbya and eukaryotic algae (b) Polysiponieae (Rhodophyta), (c) Cladophora feredayoides (Chlorophyta), (d) Sphacelaria novae-hollandiae (Phaeophyceae) and (e) Sphacelaria rigidula (Phaeophyceae). Species were selected on the basis of the magnitude of their responses ( $>10 \%$ change in one treatment). $\mathrm{n}=5$ coral chips per treatment. $\mathrm{PD}$-temp: present-day temperature; B1-temp: elevated temperature; PI: pre-industrial $\mathrm{pH}_{i} \mathrm{PD}$ : present-day $\mathrm{pH}_{i} \mathrm{~B} 1$ : $\mathrm{pH}$ treatment reflecting a $\mathrm{CO}_{2}$ scenario that is associated with significant reductions in the current rate of $\mathrm{CO}_{2}$ emissions by 2050; A1FI: pH treatment reflecting a $\mathrm{CO}_{2}$ scenario that is associated with no reduction in the current rate of $\mathrm{CO}_{2}$ emissions by 2050

under PD-temp when exposed to A1FI-pH, compared to PI-pH (2-way ANOVA, p = 0.02, Table 2). The Sphacelaria species (Phaeophyceae) showed contradicting results: while Sphacelaria novae-hollandiae Sonder showed decreased abundance under B1-temp (2-way ANOVA, p = 0.03, Table 2), Sphacelaria rigidula Kützing was more abundant at B1temp, irrespective of the $\mathrm{pH}$ (2-way ANOVA, $\mathrm{p}=$ 0.01, Table 2). Cladophora feredayoides Kraft \& A. J. K. Millar (Chlorophyta) was affected by the interaction of the factors $\mathrm{pH}$ and temperature and showed the lowest abundance under PD conditions (2-way ANOVA, p = 0.006, Table 2).

\section{Primary productivity and biomass}

The respirometry data reveal some interesting trends in turf algal productivity under different $\mathrm{pH}$ and temperature regimes (Fig. 4). The 2 factors temperature and $\mathrm{pH}$ interacted (2-way ANOVA, $\mathrm{p}=$ 0.0003 , Table 3 ), altering $\mathrm{P}_{\text {nmax }}$. Net productivity of the algae under the PI-pH/PD-temp treatment was significantly lower than that of the B1-temp treatments (for all $\mathrm{pH}$ treatments PI, PD, B1, and A1FI) as well as the A1FI-pH/PD-temp treatment. Turf assem- blages kept under the PD treatment (PD-pH/PDtemp) showed a significantly lower $\mathrm{P}_{\text {nmax }}$ than those of the PD-pH/B1-temp and the PI-pH/B1-temp treatments. Also, the algae under PD-pH/B1-temp treatment had a significantly higher $\mathrm{P}_{\text {nmax }}$ than the assemblage under B1-pH/PD-temp treatment.

Similar results were found for the LEDR. There was also a significant interaction of the 2 factors temperature and $\mathrm{pH}$ (2-way ANOVA, p = 0.046, Table 3, Fig. 4). The algae grown under PI-pH/PD-temp had the lowest LEDR compared to turf algae grown under all B1-temp treatments (PI-, PD-, B1- and A1FI-pH), as well as A1FI-pH/PD-temp conditions. Furthermore, the LEDR under PD conditions (PD-pH/PDtemp) was significantly lower than under A1FI$\mathrm{pH} / \mathrm{PD}$-temp conditions. The dark respiration of turf algae assemblages seemed to be governed by $\mathrm{pH}$ (2-way ANOVA, $p=0.001$, Table 3, Fig. 4). Turf algal assemblages under A1FI-pH had higher dark respiration than those under PI-pH and B1-pH, but did not differ from the PD-pH assemblages. The calculated GPP again showed an interactive effect between SW $\mathrm{pH}$ and temperature (2-way ANOVA, $\mathrm{p}=0.0005$, Table 3, Fig. 4), with the algae under the PI-pH/PDtemp treatment showing a lower GPP than all other treatments, except for the B1-pH/PD-temp treat- 

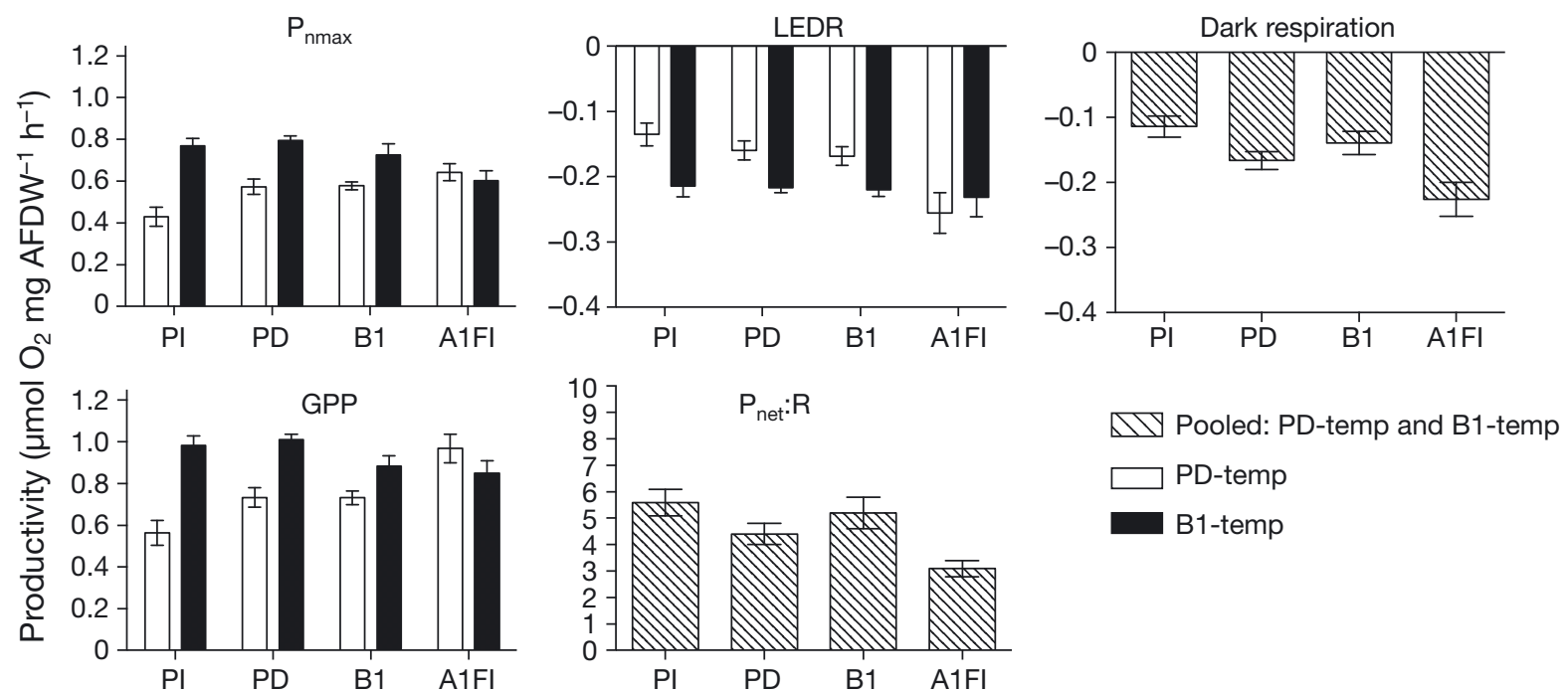

Fig. 4. Productivity of coral reef turf algae under the different $\mathrm{pH}$ and temperature regimes. Net maximum productivity $\left(\mathrm{P}_{\mathrm{nmax}}\right)$, LEDR (light-enhanced dark respiration), dark respiration, gross primary productivity (GPP) of turf algal assemblages including endolithic algae (mean $\pm \mathrm{SE}$ ) expressed as $\mu \mathrm{mol} \mathrm{O}_{2} \mathrm{mg}_{\mathrm{AFDW}}{ }^{-1} \mathrm{~h}^{-1}$ and the calculated $\mathrm{P}_{\text {net }}: \mathrm{R}$ ratio calculated from the oxygen flux data (mean $\pm \mathrm{SE}$ ). PD-temp: present-day temperature; B1-temp: elevated temperature; PI: pre-industrial $\mathrm{pH}$; PD: presentday $\mathrm{pH}_{;} \mathrm{B} 1 \mathrm{pH}$ treatment reflecting a $\mathrm{CO}_{2}$ scenario that is associated with significant reductions in the current rate of $\mathrm{CO}_{2}$ emissions by 2050; A1FI: $\mathrm{pH}$ treatment reflecting a $\mathrm{CO}_{2}$ scenario that is associated with no reduction in the current rate of $\mathrm{CO}_{2}$ emissions by 2050

Table 3. Results of the statistical analysis (2-way ANOVAs) for the respirometry data. B1T: B1-temperature; PDT: present-day temperature; PI: pre-industrial $\mathrm{pH}$ treatment; PD: present-day $\mathrm{pH}$ treatment; $\mathrm{B} 1$ : $\mathrm{pH}$ treatment reflecting a $\mathrm{CO}_{2} \mathrm{scenario}$ that is associated with significant reductions in the current rate of $\mathrm{CO}_{2}$ emissions by 2050; A1FI: $\mathrm{pH}$ treatment reflecting a CO scenario that is associated with no reduction in the current rate of $\mathrm{CO}_{2}$ emissions by 2050; ns: not significant if $\mathrm{p} \geq 0.05$

\begin{tabular}{|c|c|c|c|c|c|c|c|}
\hline $\begin{array}{l}\text { Response } \\
\text { variable }\end{array}$ & $\begin{array}{l}\text { Source of } \\
\text { variation }\end{array}$ & SS & df & MS & $F$ & $\mathrm{p}$ & $\begin{array}{l}\text { Conclusions/ } \\
\text { Post-hoc test }\end{array}$ \\
\hline \multirow[t]{3}{*}{$P_{\text {nmax }}$} & $\mathrm{pH}$ & 0.3 & 3 & 0.1 & 2.1 & 0.12 & ns \\
\hline & $\mathrm{T}$ & 1.58 & 1 & 1.58 & 33.26 & $<0.0001$ & \\
\hline & $\mathrm{T} \times \mathrm{pH}$ & 1.21 & 3 & 0.4 & 8.48 & 0.0003 & $\begin{array}{l}\mathrm{PI}_{\mathrm{PDT}}<\mathrm{PI}_{\mathrm{B} 1 \mathrm{~T}}=\mathrm{PD}_{\mathrm{B} 1 \mathrm{~T}}=\mathrm{B}_{\mathrm{B} 1 \mathrm{~T}}=\mathrm{A} 1 \mathrm{FI} \\
\mathrm{PD}_{\mathrm{PDT}}<\mathrm{PD}_{\mathrm{B} 1 \mathrm{~T}}=\mathrm{PI}_{\mathrm{B} 1 \mathrm{~T}} ; \mathrm{PD}_{\mathrm{B} 1 \mathrm{~T}}>\mathrm{B} 1_{\mathrm{PDT}}\end{array}$ \\
\hline \multirow[t]{3}{*}{ Dark respiration } & $\mathrm{pH}$ & 2.93 & 3 & 0.98 & 6.92 & 0.001 & $\mathrm{~A} 1 \mathrm{FI}>\mathrm{PI}=\mathrm{B} 1$ \\
\hline & $\mathrm{T}$ & 0.05 & 1 & 0.05 & 0.32 & 0.58 & ns \\
\hline & $\mathrm{T} \times \mathrm{pH}$ & 0.96 & 3 & 0.32 & 2.27 & 0.1 & ns \\
\hline \multirow[t]{3}{*}{ LEDR } & $\mathrm{pH}$ & 0.79 & 3 & 0.26 & 4.26 & 0.012 & \\
\hline & $\mathrm{T}$ & 0.68 & 1 & 0.68 & 10.97 & 0.002 & \\
\hline & $\mathrm{T} \times \mathrm{pH}$ & 0.55 & 3 & 0.18 & 2.97 & 0.046 & $\begin{array}{c}\mathrm{PI}_{\mathrm{PDT}}<\mathrm{PI}_{\mathrm{B} 1 \mathrm{~T}}=\mathrm{PD}_{\mathrm{B} 1 \mathrm{~T}}=\mathrm{B} 1_{\mathrm{B} 1 \mathrm{~T}}=\mathrm{A} 1 \mathrm{FI} \\
\mathrm{PD}_{\mathrm{PDT}}<\mathrm{A} 1 \mathrm{FI} \mathrm{I}_{\mathrm{PDT}}\end{array}$ \\
\hline \multirow{3}{*}{$\begin{array}{l}\text { Gross primary } \\
\text { productivity }\end{array}$} & $\mathrm{pH}$ & 0.34 & 3 & 0.11 & 2.02 & 0.13 & ns \\
\hline & $\mathrm{T}$ & 1.71 & 1 & 1.71 & 30.21 & $<0.0001$ & \\
\hline & $\mathrm{T} \times \mathrm{pH}$ & 1.3 & 3 & 0.43 & 7.65 & 0.0005 & $\begin{array}{c}\mathrm{PI}_{\mathrm{PDT}}<\mathrm{PI}_{\mathrm{B} 1 \mathrm{~T}}=\mathrm{PD}_{\mathrm{B} 1 \mathrm{~T}}=\mathrm{B} 1_{\mathrm{B} 1 \mathrm{~T}}=\mathrm{A} 1 \mathrm{FI} ; \\
\mathrm{PD}_{\mathrm{B} 1 \mathrm{~T}}>\mathrm{PD}_{\mathrm{PDT}}=\mathrm{B} 1_{\mathrm{PDT}}\end{array}$ \\
\hline \multirow[t]{3}{*}{$\mathrm{P}_{\mathrm{net}}: \mathrm{R}$} & $\mathrm{pH}$ & 0.28 & 3 & 0.09 & 7.43 & 0.0006 & $\mathrm{~A} 1 \mathrm{FI}<\mathrm{PI}=\mathrm{B} 1$ \\
\hline & $\mathrm{T}$ & 0.05 & 1 & 0.05 & 3.58 & 0.068 & ns \\
\hline & $\mathrm{T} \times \mathrm{pH}$ & 0.01 & 3 & 0.003 & 0.23 & 0.88 & ns \\
\hline
\end{tabular}

ment. The $\mathrm{P}_{\text {net }}: \mathrm{R}$ ratio calculated from the respirometry data, however, reveals another trend. Here, trends were similar to dark respiration and driven by changes in $\mathrm{pH}$, but are lower under A1FI-pH than under PI- and B1-pH (2-way ANOVA, $\mathrm{p}=0.0006$, Table 3, Fig. 4).
The biomass of the turf algae and endolithic organisms, together and separate, did not significantly vary with treatment ( $p>0.05$, results not shown). The AFDW of the turf algae and the endolithic algae was relatively balanced and varied between 0.006 and $0.009 \mathrm{~g} \mathrm{~cm}^{-2}$ for both measurements. 


\section{DISCUSSION}

The present study aimed to assess changes that might occur in coral reef turf algal assemblages in the near future by manipulating SW temperature and $\mathrm{pH}$. In the elevated temperature treatment, temperature was increased by $2.3^{\circ} \mathrm{C}$ over ambient austral spring temperatures, at a mid-latitude reef, reflecting a $\mathrm{CO}_{2}$ emission scenario that relies on reducing our present reliance on fossil fuels (B1 or 'reduced $\mathrm{CO}_{2}$ emission scenarios'). The increase in temperature is associated with a DHW of 4 half-way through the experiment, accumulating to a final DHW of 10 by the end of the experiment. The DHWs reached here suggest heating profiles that are known to place coral reefs under significant thermal stress, given that they lead to prediction of mass bleaching ( $>4$ DHW), and mortality (>8 DHW) respectively (Liu et al. 2006). Acidification levels used represent B1 or 'reduced' and A1FI or 'business-as-usual' $\mathrm{CO}_{2}$ emission scenarios, together with their $\mathrm{pH}$ ranges projected to eventuate by 2100. Interestingly, significant difference for the interaction between temperature and acidification were only noted when warming was associated with the highest acidification scenario.

The results of the present experiment demonstrated that a change in assemblage composition can be detected when considering the distinct eukaryotic species and cyanobacterial families/genera. However, coral reef turf algae do not exhibit significant changes in composition in response to $\mathrm{pH}$ and temperature treatments when analyzed at the level of genus. During the course of the experiment, brown algae became less abundant, while cyanobacteria and red algae proliferated. The changes in the distinct eukaryotic species and cyanobacterial families/ genera composition occurred due to an interactive effect between the 2 factors on algal composition. The interaction was driven by changes in abundance of representatives of cyanobacteria, red, brown and green algae identified using multi- and univariate methods. Interestingly, all the major groups had a representative species that significantly changed in abundance with treatment. The algae showed very specific responses to $\mathrm{pH}$ and temperature treatments or their interaction. In the present study, Rivulariaceae and Lyngbya were the dominant cyanobacteria but only Lyngbya increased in relative abundance over time, potentially due to increases in temperature over the course of the experiment, which started in spring and ended in summer. The dominance of Lyngbya under the combination of high acidification and temperature seemed to con- trast with the finding by Ledger \& Hildrew (2005), who found reduced abundance of freshwater cyanobacteria, under acidification treatments only. Lyngbya was able to prosper under A1FI-pH, but only when this was associated with B1-temp. Interestingly, Lyngbya and the Rivulariaceae are $\beta$-cyanobacteria possessing a type 1B RubisCO (Rae et al. 2011). This type of RubisCO relies heavily on a CCM as its affinity to $\mathrm{CO}_{2}$, and its selectivity factor for $\mathrm{CO}_{2}$ over $\mathrm{O}_{2}$ is low (Raven 1997a). A temperature increase due to climate change would be predicted to worsen the under-saturation of RubisCO; this would not, however, seem to negatively impact Lyngbya. Perhaps this is due to the presence of multiple photorespiration pathways, which are active in concert with a $\mathrm{CCM}$, under current $\mathrm{CO}_{2}$ concentrations, but do not appear to lead to the highly negative impacts typically associated with photorespiration, such as the inhibition of carbon fixation (Eisenhut et al. 2008). Cyanobacteria in general are expected to increase productivity and potentially form blooms under elevated temperature conditions (Robarts \& Zohary 1987, Paerl \& Huisman 2009, O'Neil et al. 2012). This could be deleterious to marine ecosystems in the future as, for example, one species of LyngbyaLyngbya majuscula - produces very potent metabolites that deter grazing and are toxic. Therefore a potential increase in abundance of this particular alga could be detrimental to the ecosystem (Osborne et al. 2001, O'Neil et al. 2012).

Many cyanobacteria are known to fix atmospheric nitrogen, and changes in nitrogen fixation are likely to influence the nutrient availability to the cyanobacteria themselves as well as the nutrient input into coral reefs (Webb et al. 1975). Lynbgya spp. employ a temporal mode of oxygen exclusion, enabling them to fix nitrogen at night (Berman-Frank et al. 2003, Lundgren et al. 2003). Lyngbya's nitrogen fixation may be enhanced by higher temperatures, as the activity of nitrogenase in Lyngbya has been shown to cope well with high temperatures (optimum for epilithic Hawaiian Lyngbya is $35^{\circ} \mathrm{C}_{i}$ Jones 1992). This might explain the high abundance of Lyngbya spp. under the combination of A1FI-pH and B1-temp. The Rivulariaceae did not show any such clear pattern and have a spatial mode of oxygen exclusion using heterocysts. The difference observed in growth of the 2 groups may be due to a lower optimal temperature for nitrogenase, which for Calothrix, a genus within the Rivulariaceae, has been shown to be $25^{\circ} \mathrm{C}$ (Jones 1992).

The differential responses of the algal species examined may be due to their photosynthetic bio- 
chemistry. Most eukaryotic algal RubisCO have a higher selectivity factor for $\mathrm{CO}_{2}$ over $\mathrm{O}_{2}$ than cyanobacteria. Red and brown algal Form ID RubisCOs, in particular, have relatively high selectivity factors (Raven 1997b, Tcherkez et al. 2006). Polysiphonieae benefitted from the increased $p \mathrm{CO}_{2}$ under A1FI-pH in combination with reduced photorespiration at PDtemp. The green alga Cladophora feredayoides was least abundant in the PD combination of $\mathrm{pH}$ and temperature, and seemed to benefit in its growth from altered $\mathrm{pH}$ and temperature conditions. Interestingly, the 2 species of the genus Sphacelaria showed opposing temperature preferences. The reasons for the green and brown algal responses may be a complex combination of ecological (e.g. species space competition) and physiological factors, but insufficient information is available to infer the cause for their distinct responses.

Based on the results of this study, we can expect changes in coral reef turf algal assemblages under future conditions associated with elevated atmospheric $\mathrm{CO}_{2}$. Similarly, freshwater periphyton assemblages have been shown to change notably along a pH gradient (Ledger \& Hildrew 2005). Clearly freshwater streams can exhibit lower $\mathrm{pH}$ values (4.6 to 7 ; Ledger \& Hildrew 2005), and have reduced buffering capacity. The present study shows, however, that relatively small changes in environmental parameters can significantly alter marine algal assemblages. Because most algae and especially cyanobacteria are expected to rely on CCMs, they are not expected to show any such changes or to respond positively to altered environmental conditions (Raven 1997b, Beardall et al. 1998, Beardall \& Giordano 2002). However, the results of this study indicate that species composition and abundance of algal turf assemblages may in fact change in the future.

Interestingly, no clear relationship between algal biomass and $\mathrm{pH}$ was observed, which is in agreement with Ledger \& Hildrew (2005). However, mesocosms studies conducted with specimens collected from the rocky temperate assemblages of South Australia have observed such dependence. Connell \& Russell (2010) reported significant increases in newly settled eukaryotic turf algal biomass under increased acidification (550 ppm $\mathrm{CO}_{2}, \mathrm{pH} 7.9$ ), and under a temperature increase of $3^{\circ} \mathrm{C}$ above an ambient maximum summer temperature. The greatest biomass of settling algae was observed under the combination of high $p \mathrm{CO}_{2}$ and high temperature. Connell \& Russell (2010) used a closed experimental system that contrasts significantly from our open system, in which no biomass changes were observed. Further- more, Connell \& Russell (2010) studied the response of a single genus, Feldmannia spp., settling on an empty plate with no competitors for space. In the present study, as well as that of Ledger \& Hildrew (2005), competition amongst already established and diverse algal assemblages was examined. In both studies, competition amongst groups precluded the occurrence of assemblage-wide biomass changes, other than those associated with assemblage mortality or the addition of epiphytic algal layers. Another important distinction between the present study and that of Connell \& Russell (2010) is the difference in the relative thermal stress applied. In the present study, the high temperature was $1.5^{\circ} \mathrm{C}$ above maximum long-term average monthly summer temperature (MMM), whilst in Connell \& Russell (2010), high temperature was $3^{\circ} \mathrm{C}$ above MMM. Potentially, the responses may have been different had we crossed the high acidity treatment with a higher level of thermal stress.

The productivity of the turf algal assemblage in this study is in a similar range as in situ measurements of December net productivity obtained from different assemblages of turf algae in the GBR (18 to $34 \mu \mathrm{g} \mathrm{O}_{2}$ $\mathrm{mg}_{\text {orgc }}{ }^{-1} \mathrm{~h}^{-1}$; Klumpp \& McKinnon 1989). In the present study, the net productivity was $18.4 \mu \mathrm{g} \mathrm{O}_{2}$ $\mathrm{mg}_{\mathrm{AFDW}}{ }^{-1} \mathrm{~h}^{-1}$ for the ambient temperature under control $\mathrm{pH}$ conditions, and therefore lies within the range of turf algal assemblages at that time of year.

The absence of effects on the productivity measured as biomass production under all treatments suggests that all space was occupied and that there was limited space for expansion. Conversely, oxygen flux was increased under B1-temp in the less acidic treatments (PI-pH and PD-pH), but showed a negative trend under A1FI-pH. Looking at the available data (e.g. Osborne \& Beerling 2006), an increase in productivity $\left(\mathrm{O}_{2}\right.$ flux $)$ with increases in $\mathrm{CO}_{2}$ alone, and in conjunction with temperature, is suggested in $\mathrm{C}_{3}$ terrestrial plants (compared to elevated temperature and ambient $\mathrm{CO}_{2}$ ), yet temperature alone is expected to have a negative effect on the effective quantum yield, as photorespiration would be favored. However, the interaction of temperature and $\mathrm{CO}_{2}$ is complex, and most of the aquatic organisms in the assemblage are likely to have CCMs, modifying the expected $\mathrm{C}_{3}$ response, i.e. increasing oxygen production with increasing $\mathrm{CO}_{2}$. For these reasons, as well as the diversity of the assemblage, further interpretation of these observations would be speculative.

The data suggest that possible increases of $\mathrm{P}_{\text {net }}: \mathrm{R}$ under B1-pH may be eliminated under a more acidic regime, and this ratio is therefore likely to be stable 
or reduced in the future if respiration rates increase with acidification as shown here. The latter has also been proposed by Cornwall et al. (2012); although they found a reduced CCM activity in some macroalgae under increased $p \mathrm{CO}_{2}$ (usage of $\mathrm{CO}_{2}$ increased), they did not detect an increase in photosynthesis in those species. In assemblages dominated by Lyngbya, increased dark respiration is to be expected, as nitrogen fixation at night leads to high respiration rates in other nitrogen-fixing cyanobacteria (Maryan et al. 1986, Stal \& Heyer 1987). Stored carbon is activated and used to fuel nitrogen fixation, which profits from high levels of aerobic respiration due to the coincident reduction in $\mathrm{O}_{2}$. As Lyngbya spp. were the most dominant organisms under the combination of A1FI-pH/B1-temp, their metabolism would presumably override other responses. The trend for enhanced LEDR under B1-temp and PI-, PD- and B1-pH can be explained by increased photorespiration under elevated temperature, which would be negated under A1FI-pH, where RubisCO seems to be $\mathrm{CO}_{2}$-saturated and hence the elevated temperature effect is absent. Alternatively, LEDR may have been enhanced due to an increased concentration of Calvin cycle products or chlororespiration, given that the measurement is taken in the dark (Reddy et al. 1991, Beardall et al. 2003, Parys \& Jastrzebski 2006).

In conclusion, we observed changes in the assemblage composition of coral reef turf algae under elevated temperature and ocean acidification conditions. The highly diverse eukaryotic component of the turf algal assemblage responded differentially to the altered conditions. However, the prokaryotic component comprised primarily of Lyngbya seemed to respond to these changed environmental conditions in a more competitive manner, dominating the low $\mathrm{pH}$ and high temperature treatment. Under the experimental conditions turf biomass was stable; however, productivity (as in oxygen flux) was governed by a complex interaction of the factors. The results suggest that Lyngbya spp. have the potential not only to outcompete co-existing turf algae, but also to spread into open space, should it be made available under future conditions (e.g. due to increased coral bleaching and mortality). Clearly, further experiments are required to determine (1) whether, given a greater expanse of open dead coral substrata, Lyngbya will become the dominate genus under future scenarios; and (2) the effect of treatments on the palatability and nutritional value for grazers, particularly given the critical role they play in regulating algal abundance in reefs. However, given that future climates under 'fossil fuel intensive scenarios' are set to experience warmer seas than were applied in this study, experiments combining higher temperatures with high acidifications would also seem to be of paramount importance, to determine the fate of coral reef turf algae under potential climates occurring if 'business as usual' emissions continue.

Acknowledgements. This research was funded by the ARC Centre of Excellence for Coral Reef Studies (CE0561435), ARC-L grant (LP0989845), the Queensland Government Smart State Premier's Fellowship awarded to Prof. O. Hoegh-Guldberg and supported by the Great Barrier Reef Foundation, and the Yulgilbar Foundation Fellowship awarded to G.D.P.

\section{LITERATURE CITED}

Abbott IA (1999) Marine red algae of the Hawaiian Islands. Bishop Museum Press, Honolulu, Hawaii, HI

Abbott IA, Huisman JM (2004) Marine green and brown algae of the Hawaiian Islands. Bishop Museum Press, Honolulu, Hawaii, HI

Adey WH, Goertemiller T (1987) Coral reef algal turfs: master producers in nutrient poor seas. Phycologia 26: 374-386

Anagnostidis K, Komárek J (1988) Modern approach to the classification system of cyanophytes. 3. Oscillatoriales. Supplementband 80, Algol Stud/Archiv für Hydrobiol 50-53:327-472

Beardall J, Giordano M (2002) Ecological implications of microalgal and cyanobacterial $\mathrm{CO}_{2}$ concentrating mechanisms, and their regulation. Funct Plant Biol 29:335-347

> Beardall J, Beer S, Raven JA (1998) Biodiversity of marine plants in an era of climate change: some predictions based on physiological performance. Bot Mar 41:113-124

Beardall J, Quigg A, Raven J (2003) Oxygen consumption: photorespiration and chlororespiration. In: Larkum AD, Douglas S, Raven J (eds) Photosynthesis in algae. Kluwer, Dordrecht, p 157-181

> Berman-Frank I, Lundgren P, Falkowski P (2003) Nitrogen fixation and photosynthetic oxygen evolution in cyanobacteria. Res Microbiol 154:157-164

Borowitzka MA, Day RW, Larkum AWD (1983) The importance of primary production by turf and crustose algal communities in One Tree Lagoon. In: Baker JT, Carter RM, Sammarco PW, Stark KP (eds) Proc Inaugural Great Barrier Reef Conf, 28 Aug-2 Sep 1983. James Cook University Press, Townsville, p 287-292

Connell SD, Russell BD (2010) The direct effects of increasing $\mathrm{CO}_{2}$ and temperature on non-calcifying organisms: increasing the potential for phase shifts in kelp forests. Proc R Soc Lond B Biol Sci 277:1409-1415

Cornwall CE, Hepburn CD, Pritchard D, Currie KI, McGraw CM, Hunter KA, Hurd CL (2012) Carbon-use strategies in macroalgae: differential responses to lowered $\mathrm{pH}$ and implications for ocean acidification. J Phycol 48:137-144

Crawley A, Kline DI, Dunn S, Anthony KRN, Dove S (2010) The effect of ocean acidification on symbiont photorespiration and productivity in Acropora formosa. Glob Change Biol 16:851-863 
Davison IR (1991) Environmental effects on algal photosynthesis: temperature. J Phycol 27:2-8

- Diaz-Pulido G, McCook LJ (2002) The fate of bleached corals: patterns and dynamics of algal recruitment. Mar Ecol Prog Ser 232:115-128

> Diaz-Pulido G, Gouezo M, Tilbrook B, Dove S, Anthony KRN (2011) High $\mathrm{CO}_{2}$ enhances the competitive strength of seaweeds over corals. Ecol Lett 14:156-162

> Diaz-Pulido G, Nash MC, Anthony KRN, Bender D, Opdyke BN, Reyes-Nivia M, Troitzsch U (2014) Greenhouse conditions induce mineralogical changes and dolomite accumulation in coralline algae on tropical reefs. Nat Commun 3310:1-9

> Dickson AG, Millero FJ (1987) A comparison of the equilibrium-constants for the dissociation of carbonic-acid in seawater media. Deep-Sea Res 34:1733-1743

> Doney SC, Ruckelshaus M, Emmett Duffy J, Barry JP and others (2012) Climate change impacts on marine ecosystems. Annu Rev Mar Sci 4:11-37

$>$ Dove SG, Kline DI, Pantos O, Angly FE, Tyson GW, HoeghGuldberg O (2013) Future reef decalcification under a business-as-usual $\mathrm{CO}_{2}$ emission scenario. Proc Natl Acad Sci USA 110:15342-15347

Eisenhut M, Ruth W, Haimovich M, Bauwe H, Kaplan A, Hagemann M (2008) The photorespiratory glycolate metabolism is essential for cyanobacteria and might have been conveyed endosymbiontically to plants. Proc Natl Acad Sci USA 105:17199-17204

Enriquez S, Rodriguez-Román A (2006) Effect of water flow on the photosynthesis of three marine macrophytes from a fringing-reef lagoon. Mar Ecol Prog Ser 323:119-132

Hatcher BG (1988) Coral reef primary productivity: a beggar's banquet. Trends Ecol Evol 3:106-111

Heil CA, Chaston K, Jones A, Bird P and others (2004) Benthic microalgae in coral reef sediments of the southern Great Barrier Reef, Australia. Coral Reefs 23:336-343

Hoegh-Guldberg O, Bruno JF (2010) The impact of climate change on the world's marine ecosystems. Science 328: 1523-1528

Hoegh-Guldberg O, Mumby PJ, Hooten AJ, Steneck RS and others (2007) Coral reefs under rapid climate change and ocean acidification. Science 318:1737-1742

Holbrook GP, Beer S, Spencer WE, Reiskind JB and others (1988) Photosynthesis in marine macroalgae: evidence for carbon limitation. Can J Bot 66:577-582

> Hughes TP, Graham NAJ, Jackson JBC, Mumby PJ, Steneck RS (2010) Rising to the challenge of sustaining coral reef resilience. Trends Ecol Evol 25:633-642

IPCC (2007) Fourth Assessment Report of the Intergovernmental Panel on Climate Change (IPCC). Cambridge University Press, Cambridge

Ives AR, Carpenter SR (2007) Stability and diversity of ecosystems. Science 317:58-62

Johnson MD, Price NN, Smith JE (2014) Contrasting effects of ocean acidification on tropical fleshy and calcareous algae. PeerJ 2:e411

> Jones K (1992) Diurnal nitrogen fixation in tropical marine cyanobacteria: a comparison between adjacent communities of non-heterocystous Lyngbya sp. and heterocystous Calothrix sp. Br Phycol J 27:107-118

> Kim MS, Abbott IA (2006) Taxonomic notes on Hawaiian Polysiphonia, with transfer to Neosiphonia (Rhodomelaceae, Rhodophyta). Phycol Res 54:32-39

Klumpp DW, McKinnon AD (1989) Temporal and spatial patterns in primary production of a coral-reef epilithic algal community. J Exp Mar Biol Ecol 131:1-22

> Klumpp DW, McKinnon AD (1992) Community structure, biomass and productivity of epilithic algal communities on the Great-Barrier-Reef: dynamics at different spatial scales. Mar Ecol Prog Ser 86:77-89

Klumpp DW, McKinnon D, Daniel P (1987) Damselfish territories: zones of high productivity on coral reefs. Mar Ecol Prog Ser 40:41-51

Koop K, Booth D, Broadbent A, Brodie J and others (2001) ENCORE: the effect of nutrient enrichment on coral reefs. Synthesis of results and conclusions. Mar Pollut Bull 42:91-120

Kraft GT (2007) Algae of Australia: marine benthic algae of Lord Howe Island and the Southern Great Barrier Reef, Vol 1. Green algae. ABRS, Canberra; CSIRO Publishing, Melbourne

Kübler JE, Raven JA (1994) Consequences of light limitation for carbon acquisition in three rhodophytes. Mar Ecol Prog Ser 110:203-209

> Larkum AWD, Kennedy IR, Muller WJ (1988) Nitrogen fixation on a coral reef. Mar Biol 98:143-155

- Ledger ME, Hildrew AG (2005) The ecology of acidification and recovery: changes in herbivore-algal food web linkages across a stream pH gradient. Environ Pollut 137: 103-118

Lewis E, Wallace D (1997) Ocean $\mathrm{CO}_{2}$. http://cdiac.ornl.gov/ oceans/co2rprt.html (accessed 30 Sep 2012)

Liu G, Strong AE, Skirving W, Arzayus LF (2006) Overview of NOAA Coral Reef Watch Program's near-real time global satellite coral bleaching monitoring activities. Proc 10th Int Coral Reef Symp, Okinawa, 1:1783-1793

Lundgren P, Bauer K, Lugomela C, Söderbäck E, Bergman B (2003) Reevaluation of the nitrogen fixation behavior in the marine non-heterocystous cyanobacterium Lyngbya majuscula. J Phycol 39:310-314

Maryan PS, Eady RR, Chaplin AE, Gallon JR (1986) Nitrogen fixation by Gloeothece sp. PCC 6909: respiration and not photosynthesis supports nitrogenase activity in the light. J Gen Microbiol 132:789-796

Mehrbach C, Culberso CH, Hawley JE, Pytkowic RM (1973) Measurement of apparent dissociation-constants of carbonic-acid in seawater at atmospheric-pressure. Limnol Oceanogr 18:897-907

Moazami-Goudarzi M, Colman B (2012) Changes in carbon uptake mechanisms in two green marine algae by reduced seawater $\mathrm{pH}$. J Exp Mar Biol Ecol 413:94-99

NOAA (2011) NOAA Coral Reef Watch methodology, product description, and data availability of NOAA Coral Reef Watch (CRW) operational and experimental satellite coral bleaching monitoring products. http://coralreefwatch. noaa.gov/satellite/methodology/methodology.php (accessed 6 Sep 2012)

NOAA (2014) Data time series Lizard Island. http://coralreef watch.noaa.gov/satellite/vs/data_timeseries/vs_ts_Lizard Island_GBR.txt (accessed Sept 2012)

> Nyström M, Folke C, Moberg F (2000) Coral reef disturbance and resilience in a human-dominated environment. Trends Ecol Evol 15:413-417

Nyström M, Graham NAJ, Lokrantz J, Norström AV (2008) Capturing the cornerstones of coral reef resilience: linking theory to practice. Coral Reefs 27:795-809

O'Neil JM, Davis TW, Burford MA, Gobler CJ (2012) The rise of harmful cyanobacteria blooms: the potential roles of eutrophication and climate change. Harmful Algae 14: 313-334 
Osborne CP, Beerling DJ (2006) Nature's green revolution: the remarkable evolutionary rise of $\mathrm{C} 4$ plants. Philos Trans R Soc Lond Ser B Biol Sci 361:173-194

Osborne NJT, Webb PM, Shaw GR (2001) The toxins of Lyngbya majuscula and their human and ecological health effects. Environ Int 27:381-392

Paerl HW, Huisman J (2009) Climate change: a catalyst for global expansion of harmful cyanobacterial blooms. Environ Microbiol Rep 1:27-37

Parys E, Jastrzebski H (2006) Light-enhanced dark respiration in leaves, isolated cells and protoplasts of various types of C4 plants. J Plant Physiol 163:638-647

Paul VJ (2008) Global warming and cyanobacterial harmful algal blooms: In: Hudnell HK (ed) Cyanobacterial harmful algal blooms: state of the science and research needs, Vol 619. Springer, New York, NY, p 239-257

Price IR, Scott FJ (1992) The turf algal flora of the Great Barrier Reef. I. Rhodophyta. James Cook University, Townsville

$>$ Rae BD, Förster B, Badger M, Dean Price G (2011) The $\mathrm{CO}_{2}$ concentrating mechanism of Synechococcus WH5701 is composed of native and horizontally-acquired components. Photosynth Res 109:59-72

Raven JA (1997a) Inorganic carbon acquisition by marine autotrophs. Adv Bot Res 27:85-209

Raven JA (1997b) Putting the C in phycology. Eur J Phycol 32:319-333

Raven JA (2003) Inorganic carbon concentrating mechanisms in relation to the biology of algae. Photosynth Res 77:155-171

Raven JA, Ball LA, Beardall J, Giordano M, Maberly SC (2005) Algae lacking carbon-concentrating mechanisms. Can J Bot 83:879-890

Reddy MM, Vani T, Raghavendra AS (1991) Light-enhanced dark respiration in mesophyll protoplasts from leaves of pea. Plant Physiol 96:1368-1371

Robarts RD, Zohary T (1987) Temperature effects on photosynthetic capacity, respiration, and growth rates of bloomforming cyanobacteria. NZ J Mar Freshw Res 21:391-399

Editorial responsibility: Charles Birkeland,

Honolulu, Hawaii, USA
Russell BD, Thompson JAI, Falkenberg LJ, Connell SD (2009) Synergistic effects of climate change and local stressors: $\mathrm{CO}_{2}$ and nutrient-driven change in subtidal rocky habitats. Glob Change Biol 15:2153-2162

Schlichter D, Kampmann H, Conrady S (1997) Trophic potential and photoecology of endolithic algae living within coral skeletons. Mar Ecol 18:299-317

Stal LJ, Heyer H (1987) Dark anaerobic nitrogen fixation (acetylene reduction) in the cyanobacterium Oscillatoria sp. FEMS Microbiol Lett 45:227-232

Steneck RS (1988) Herbivory on coral reefs: a synthesis. Proc 6th Int Coral Reef Symp, Townsville 1:37-49

Targett NM, Boettcher AA, Targett TE, Vrolijk NH (1995) Tropical marine herbivore assimilation of phenolic-rich plants. Oecologia 103:170-179

Tcherkez GGB, Farquhar GD, Andrews TJ (2006) Despite slow catalysis and confused substrate specificity, all ribulose bisphosphate carboxylases may be nearly perfectly optimized. Proc Natl Acad Sci USA 103: 7246-7251

Wanders JBW (1976) The role of benthic algae in the shallow reef of Curacao (Netherlands Antilles). I. Primary productivity in the coral reef. Aquat Bot 2:235-270

Webb KL, Dupaul WD, Wiebe W, Sottile W, Johannes RE (1975) Enewetak (Eniwetok) Atoll - aspects of nitrogen cycle on a coral-reef. Limnol Oceanogr 20:198-210

Womersley HBS (1984) The marine benthic flora of southern Australia. 1. Chlorophyta. Australian Biological Resources Study, Canberra

Womersley HBS (1987) The marine benthic flora of southern Australia. II. Phaeophyta. Australian Biological Resources Study, Canberra

Womersley HBS (2003) The marine benthic flora of southern Australia. IIID. Ceramiales - Delesseriaceae, Sarcomeniaceae, Rhodomelaceae. Australian Biological Resources Study, Canberra

Zeebe RE, Wolf-Gladrow D (2001) $\mathrm{CO}_{2}$ in seawater: equilibrium, kinetics, isotopes, Vol 65. Elsevier Oceanography Series, Elsevier Science, Amsterdam

Submitted: April 17, 2014; Accepted: September 10, 2014 Proofs received from author(s): December 3, 2014 